\title{
HUBUNGAN ANTARA PENGETAHUAN REMAJA PEREMPUAN TENTANG KEKERASAN DALAM PACARAN, LAMANYA PACARAN DAN KECERDASAN EMOSIONAL DENGAN KEJADIAN KEKERASAN DALAM PACARAN DI SMAN 9 CIREBON TAHUN 2014
}

\author{
Nina Nirmaya Mariani ${ }^{1}$, Yayu Indah Mentari ${ }^{2}$ \\ ${ }^{1}$ Dosen Prodi D4 Kebidanan Cirebon Poltekkes Kemenkes Tasikmalaya
}

\begin{abstract}
ABSTRAK
Mayoritas remaja yang sedang berpacaran tidak menyadari bahwa dalam sebuah hubungan pacaran seringkali berisiko mengarah pada perlakuan buruk yang dilakukan oleh pasangan (dating violence). Tercatat dari 1994-2011 (Januari-Oktober), dating violence menempati posisi kedua (836 kasus) setelah KDRT yang ditangani oleh Rifka Annisa. Penelitian ini bertujuan untuk mengetahui hubungan antara pengetahuan remaja perempuan, lamanya pacaran dan kecerdasan emosional dengan kejadian kekerasan dalam pacaran di SMAN 9 Cirebon Tahun 2014. Metode penelitian menggunakan analitik dengan pendekatan cross sectional. Subjek penelitian adalah seluruh siswi perempuan kelas $\mathrm{X}$ dan $\mathrm{XI}$ dengan menggunakan purposive sampling dengan jumlah sampel 162. Pengumpulan data menggunakan kuesioner. Uji statistik menggunakan Chi Square dengan tingkat kepercayaan $\alpha=0,05$. Hasil penelitian didapatkan mayoritas memiliki pengetahuan cukup sebanyak 62,3 $\%$, memiliki lamanya pacaran $>6$ bulan sebanyak $56,2 \%$, mayoritas memiliki kecerdasan rendah sebanyak $51,9 \%$. Berdasarkan analisis bivariat menunjukan adanya hubungan antara pengetahuan remaja perempuan $(p$ value $=0,002)$ dan lamanya pacaran ( $p$ value $=$ 0,000 ) dengan kejadian kekerasan dalam pacaran, tidak ada hubungan antara kecerdasan emosional ( $p$ value $=0,750$ ) dengan kejadian kekerasan dalam pacaran. Diharapkan pihak sekolah dan tenaga kesehatan tetap mengadakan penyuluhan kesehatan reproduksi termasuk materi kekerasan dalam pacaran.
\end{abstract}

Kata kunci : pengetahuan, lamanya pacaran, kecerdasan emosional, kekerasan pacaran

\begin{abstract}
The majority of teens being involved in a romantic relationship do not realize that a dating relationship often leads to the risk of ill-treatment committed by the partner (dating violence). It was recorded from 1994 to 2011 (January-October) that dating violence took second place (836 cases) after domestic violence handled by Rifka Annisa. This study aimed to determine the relationship between the knowledge of adolescent girls, the length of dating and emotional intelligence and the incidence of dating violence at SMAN 9 Cirebon in 2014. This was an analytic study with a cross sectional approach. The research subject was the entire female students of class $X$ and $X I$ by using purposive sampling with a sample of 162 . The data was collected using a questionnaire. This study used the Chi Square statistical test with a confidence level $\alpha=0.05$. The result showed that the majority $62.3 \%$ had sufficient knowledge, 56.2\% had a dating duration more than 6 months, and 51.9\% had lower intelligence. Based on bivariate analysis, there was an association between the knowledge of adolescent girls ( $p$ value $=0.002)$ and the length of dating $(p$ value $=0.000)$ and the incidence of dating violence but no correlation between emotional intelligence ( $p$ value $=$ 0.750) and the incidence of dating violence. It is expected that school and health professionals keep holding reproductive health education including violent material in dating.
\end{abstract}

Keywords : knowledge, the length of dating, emotional intelligence, dating violence 


\section{PENDAHULUAN}

Masa remaja merupakan masa peralihan dari masa kanak-kanak menuju masa dewasa, dimana pada masa itu terjadi pertumbuhan yang pesat termasuk fungsi reproduksi sehingga mempengaruhi terjadinya perubahan perkembangan, baik fisik, mental maupun peran sosial (Komalasari, 2012). Remaja mempelajari perilaku orang dewasa sesuai dengan jenis kelamin untuk menarik perhatian lawan jenisnya, ia mulai mencari informasi tentang kehidupan seksual orang dewasa, bahkan juga muncul rasa ingin tahu dan keinginan bereksplorasi untuk melakukannya. Apabila hal tersebut tidak dapat dikendalikan maka akan mengarah pada hal-hal yang tidak diinginkan (Set, 2009).

Salah satu kegiatan sosial yang dilakukan remaja adalah pacaran (dating) yang melibatkan remaja perempuan dan lakilaki. Pacaran adalah sebuah proses saling mengenal, memahami dan menghargai perbedaan diantara dua individu. Rasa cinta terhadap lawan jenis mengakibatkan mereka terlibat dalam hubungan pacaran. (Hidayati dan Mashum, 2002) yang dikutip oleh Untari (2008).

Lingkungan sekolah merupakan salah satu tempat dimana remaja banyak menghabiskan waktu dibandingkan dengan kebersamaan mereka dengan orangtua di rumah, sehingga kesempatan untuk berkenalan dan menjajaki hubungan cinta lebih terbuka. Kondisi demikian menjadi pemicu terjadinya dating di kalangan pelajar, dan secara tidak langsung hal tersebut memicu terjadinya kekerasan dalam pacaran. Pada awalnya motivasi para remaja untuk melakukan dating murni berasal dari cinta dan rasa ingin memiliki. Namun, dalam pacaran, kadang justru tidak jarang terjadi tindak kekerasan (Set, 2009).

Kekerasan dalam pacaran (dating violence) adalah tindak kekerasan terhadap pasangan yang belum terikat pernikahan yang mencakupi kekerasan fisik seperti memukul, menampar, menendang, mendorong, mencengkram dengan keras pada tubuh pasangan dan serangkaian tindakan fisik yang lain, kekerasan psikologi, kekerasan ekonomi, kekerasan seksual dan stalking (Annisa, 2012).

Tindakan kekerasan dalam pacaran memiliki dampak negatif yang sangat mempengaruhi kehidupan remaja itu sendiri. Adapun dampak dari kekerasan dalam pacaran diantaranya luka fisik (luka ringan atau berat), dampak psikis ( perasaan cemas, murung, prestasi menurun, gangguan pola makan hingga depresi bahkan melakukan tindakan yang menyakiti dirinya sendiri atau bunuh diri), untuk kasus kekerasan seksual (pemakasaan hubungan seksual) dampaknya bisa menyebabkan kehamilan yang tidak diinginkan yang berujung pada tindakan aborsi yang tidak aman (Set, 2009).

Hal tersebut sesuai dengan ungkapan Rifka Annisa menyatakan bahwa dating violence menempati posisi kedua setelah kekerasan dalam rumah tangga. Tercatat dari 1994-2011 (Januari-Oktober), Rifka Annisa telah menangani 4952 kasus kekerasan pada perempuan, posisi pertama kasus KDRT sebanyak 3274 kasus, dan posisi kedua kasus dating violance tercatat 836 kasus (Annisa, 2012).

Kondisi di atas sesuai dengan hasil penelitian yang dilakukan oleh Suci Mustiva Ayu (2011), ditemukan gambaran kekerasan fisik yaitu dipukul oleh pacar/pasangannya sebanyak 30,83\%. Gambaran kekerasan seksual yaitu dicium paksa oleh pacar/pasangan sebesar 34,17\%. Gambaran kekerasan emosi yaitu tanpa kerelaan membelikan pulsa untuk pacar/pasangan sebanyak 25,83\%. Gambaran kekerasan emosi yaitu merasa tersinggung atas perlakuan pacar/pasangan yang menjadikannya sebagai bahan tertawaan di depan umum sebanyak $17,5 \%$.

Selain penelitian di atas, berdasarkan studi pendahuluan yang dilakukan peneliti, dari 20 responden siswi kelas XI SMAN 9 Cirebon terdapat 3 responden tidak pernah berpacaran sehingga tidak akan mengalami kekerasan dalam pacaran, 3 responden sedang berpacaran tetapi tidak mengalami kekerasan dalam pacaran. Selebihnya 
terdapat 14 responden yang pernah mengalami kekerasan dalam pacaran. Mereka merasakan ketidaknyamanan, ketidaknyamanan tersebut disebabkan pacar sering cemburu, membatasi aktivitas seharihari, membatasi bergaul dengan orang lain, ditampar oleh pacarnya dan 1 responden mengatakan pernah diajak melakukan hal negatif tetapi responden menolaknya.

Berbagai faktor yang menjadi pemicu terjadinya kekerasan dalam pacaran diantaranya adalah pengetahuan remaja tentang kekerasan dalam pacaran, lamanya pacaran dan kecerdasan emosional. Remaja yang memiliki pengetahuan baik tentang kekerasan dalam pacaran memiliki risiko rendah mengalami kekerasan, karena dengan pengetahuan yang baik mereka akan menolak kekerasan tersebut (Yuhani,2012). Keadaan tersebut sesuai dengan penelitian yang dilakukan oleh Gracia Ferlita (2008) yang menyatakan bahwa remaja cenderung bersikap negatif atau menolak kekerasan dalam berpacaran, mereka mengetahui bahwa kekerasan adalah hal yang tidak wajar untuk dilakukan dengan alasan cinta.

Selain itu, faktor yang mempengaruhi kekerasan dalam pacaran adalah lamanya pacaran. Semakin lama seseorang menjalin hubungan pacaran (dating) maka semakin berisiko terjadi kekerasan dalam pacaran, korban merasa kesulitan untuk menolak atau melawannya karena rasa sayang atau cinta terhadap pasangannya sudah besar. Menurut

\section{METODE PENELITIAN}

Penelitian ini menggunakan metode analitik dengan pendekatan cross sectional. Lokasi penelitian di SMAN 9 Cirebon dengan waktu penelitian yaitu Maret-Mei tahun 2014. Populasi dalam penelitian ini adalah seluruh siswi kelas X dan XI SMAN 9 Cirebon yang berjumlah 183 orang. Kelas XII tidak dimasukkan sebagai populasi karena sedang sibuk untuk persiapan Ujian Nasional. Peneliti mengambil sampel dengan teknik purposive sampling. Sampel dalam penelitian adalah seluruh siswi kelas $X$ dan XI SMAN 9 Cirebon yang memenuhi kriteria sampel. Jumlah responden yang memenuhi kriteria inklusi
Billingham, Riggs \& O'Leangry dalam Luthra \& Gidycz (2006) dating violence lebih sering terjadi pada hubungan yang lebih serius dan dalam durasi yang cukup lama yaitu setiap pertambahan durasi 6 bulan, maka kekerasan dalam hubungan tersebut akan semakin meningkat.

Faktor lain yang memicu terjadinya kekerasan dalam pacaran adalah kecerdasan emosional. Kecerdasan emosional adalah kemampuan memantau diri sendiri dan perasaan orang lain serta menggunakan informasi untuk mengarahkan pikiran dan tindakan. Shapiro (1997) menekankan kecerdasan emosional pada pengelolaan emosi untuk mengontrol perilaku sendiri yang dikutip oleh Saam Zulfan (2012). Keberhasilan atau kegagalan seseorang dalam mengelola emosinya menurut Goleman (1995) tergantung pada apa yang dinamakan Kecerdasan Emosional (Emotional Intelligence). Pernyataan diatas didukung oleh pendapat Sarlito W. Sarwono (2010) makin tinggi kecerdasan emosi seseorang, makin bisa ia mengatasi berbagai masalah, khususnya yang memerlukan kendali emosi yang kuat.

Tujuan penelitian ini adalah untuk mengetahui hubungan antara pengetahuan remaja perempuan tentang kekerasan dalam pacaran, lamanya pacaran, dan kecerdasan emosional dengan kejadian kekerasan dalam pacaran di SMAN 9 Cirebon Kota Cirebon Tahun 2014

yaitu sebanyak 162 orang. Sedangkan responden yang memenuhi keriteria eksklusi yaitu sebanyak 9 orang. Adapun kriteria Inklusi yaitu Siswi kelas X dan XI SMAN 9 Cirebon, sedang berpacaran atau pernah berpacaran dan bersedia menjadi responden sedangkan kriteria eksklusi adalah tidak hadir saat pengambilan data. Jenis pengumpulan data yang digunakan berupa kuesioner tertutup dan hanya menjawab pertanyaan dengan memilih jawaban yang tersedia.

Analisis data dalam penelitian ini adalah analisis univariat. Analisis univariat bertujuan untuk menjelaskan atau mendeskripsikan 
karakteristik setiap variabel penelitian. Pada umumnya dalam analisis ini hanya menghasilkan distribusi frekuensi dan presentase dari tiap variabel (Notoatmodjo, 2012). Adapun analisis univariat dalam penelitian ini dibuat dalam bentuk tabel frekuensi (persentase).

Analisis bivariat yang dilakukan terhadap 2 variabel yang diduga berhubungan atau berkolerasi. Uji statistik yang digunakan yaitu chi square untuk melihat hubungan 2 variabel tersebut bermakna atau tidak bermakna
(Notoatmodjo, 2012) dengan tingkat kepercayaan $\alpha=0,05$. Metode pengujian hipotesis dengan menggunakan perangkat lunak SPSS versi 18. Adapun interpretasi dari analisis yang dilakukan adalah bila nilai $p$ value $\leq 0,05$, maka $\mathrm{H}_{0}$ ditolak yang berarti terdapat hubungan yang bermakna antara variabel independen dan variabel dependen. Tetapi bila nilai $p$ value $>0,05$, maka $\mathrm{H}_{0}$ diterima yang berarti tidak terdapat hubungan yang bermakna antara variabel independen dan variabel dependen.

\section{HASIL PENELITIAN}

Tabel 1. Distribusi frekuensi pengetahuan remaja perempuan tentang kekerasan dalam pacaran, lamanya pacaran, kecerdasan emosional dan kejadian kekerasa dalam pacaran di SMAN 9 Cirebon Tahun 2014

\begin{tabular}{ccc}
\hline Variabel & \multicolumn{2}{c}{ Total } \\
\cline { 2 - 3 } & $\mathbf{N}$ & $\%$ \\
\hline Pengetahuan & 18 & 11,1 \\
Baik & 101 & 62,3 \\
Cukup & 43 & 26,5 \\
Kurang & & \\
Lamanya pacaran & 71 & 43,8 \\
6 bulan & 91 & 56,2 \\
>6 bulan & 78 & 48,1 \\
Kecerdasan Emosional & 84 & 51,9 \\
Tinggi & & 34,6 \\
Rendah & 56 & 65,4 \\
\hline Kejadian Kekerasan & 106 & \\
Tidak Mengalami & &
\end{tabular}

Berdasarkan tabel 1 di atas, dari hasil penelitian kepada 162 orang didapatkan mayoritas remaja perempuan di SMAN 9 Cirebon memiliki pengetahuan cukup yaitu sebanyak $62,3 \%$ atau 101 orang, memiliki durasi lamanya pacaran selama $>6$ bulan yaitu sebanyak $56,2 \%$ atau 91 orang, memiliki kecerdasan emosional rendah yaitu sebanyak $51,9 \%$ atau 84 orang dan mengalami kekerasan dalam pacaran yaitu sebanyak $65,4 \%$ atau 106 orang.

Berdasarkan tabel 2 di bawah didapatkan bahwa pengetahuan remaja tentang kesehatan reproduksi didapatkan nilai $p$ value $=0,002<\alpha=0,005$, maka dapat disimpulkan $\mathrm{H}_{0}$ ditolak yang artinya terdapat hubungan yang bermakna antara pengetahuan remaja perempuan tentang kekerasan dalam pacaran dengan kejadian kekerasan dalam pacaran di SMAN 9 Cirebon Tahun 2014. Lamanya pacaran didapatkan hasil uji hipotesis dengan nilai $p$ value $=0,000$ $<\alpha=0,005$, maka dapat disimpulkan $\mathrm{H}_{0}$ ditolak yang artinya terdapat hubungan yang bermakna antara lamanya pacaran dengan kejadian kekerasan dalam pacaran di SMAN 9 Cirebon Tahun 2014. Sedangkan dari hasil uji hipotesis berdasarkan kecerdasan emosional didapatkan nilai $p$-value $=0,750>$ $\alpha=0,005$, maka dapat disimpulkan $\mathrm{H}_{0}$ diterima yang artinya tidak terdapat hubungan yang bermakna antara kecerdasan emosional dengan kejadian kekerasan dalam pacaran di SMAN 9 Cirebon Tahun 2014 
Nina N.M. dan Yayu I.M., Poltekkes Tasikmalaya: pengetahuan, kecerdasan, kekerasan, pacaran

Tabel 2. Hubungan antara pengetahuan remaja perempuan tentang kekerasan dalam pacaran, lamanya pacaran dan kecerdasan emosional dengan kejadian kekerasan dalam pacaran di SMAN 9 Tahun 2014

\begin{tabular}{|c|c|c|c|c|c|c|c|}
\hline \multirow{3}{*}{ Variabel } & \multicolumn{4}{|c|}{ Kejadian } & \multirow{2}{*}{\multicolumn{2}{|c|}{ Total }} & \multirow{3}{*}{$P$ value } \\
\hline & \multicolumn{2}{|c|}{ Tidak Mengalami } & \multicolumn{2}{|c|}{ Mengalami } & & & \\
\hline & $\mathbf{N}$ & $\%$ & $\mathbf{N}$ & $\%$ & $\mathbf{N}$ & $\%$ & \\
\hline \multicolumn{8}{|l|}{ Pengetahuan } \\
\hline Baik & 13 & 72,2 & 5 & 27,8 & 18 & 100 & \multirow{3}{*}{0,002} \\
\hline Cukup & 31 & 30,7 & 70 & 69,3 & 101 & 100 & \\
\hline Kurang & 12 & 27,9 & 31 & 72,1 & 43 & 100 & \\
\hline \multicolumn{8}{|l|}{ Lamanya pacaran } \\
\hline$\leq 6$ bulan & 40 & 56,3 & 31 & 43,7 & 71 & 100 & \multirow[t]{2}{*}{0,000} \\
\hline$>6$ bulan & 16 & 17,6 & 75 & 82,4 & 91 & 100 & \\
\hline \multicolumn{8}{|c|}{ Kecerdasan emosional } \\
\hline Tinggi & 26 & 33,3 & 52 & 66,7 & 78 & 100 & \multirow[t]{2}{*}{0,750} \\
\hline Rendah & 30 & 35,7 & 54 & 64,3 & 84 & 100 & \\
\hline
\end{tabular}

\section{PEMBAHASAN}

1. Pengetahuan remaja tentang kesehatan reproduksi

Hasil penelitian yang dilakukan di SMAN

9 Cirebon kepada 162 responden, didapatkan hasil yaitu ada hubungan antara pengetahuan remaja perempuan tentang kekerasan dalam pacaran dengan kejadian kekerasan dalam pacaran di SMAN 9 Cirebon Tahun 2014. Hal ini sesuai dengan pendapat yang dikemukakan Wawan (2011) bahwa pengetahuan seseorang tentang suatu objek mengandung dua aspek yaitu aspek positif dan aspek negatif. Kedua aspek ini yang akan menentukan sikap seseorang (menolak atau menerima). Semakin banyak aspek positif dan objek yang diketahui, maka akan menimbulkan sikap makin positif terhadap objek tertentu.

Berdasarkan hasil penelitian sebagian besar responden merasa senang saat berpacaran, hal tersebut dapat diakibatkan karena mereka menganggap yang dilakukan oleh pasangan itu hal wajar. Mereka tidak sadar atau tidak tahu hal yang dilakukan oleh pasangan merupakan kekerasan. Hal ini sesuai dengan pendapat yang dikemukakan oleh Sony (2009) yang mengungkapkan bahwa pacaran yang merupakan masa indah bagi setiap manusia, kadang justru tidak jarang terjadi tindak kekerasan didalamnya, sebagian besar dari mereka tidak menyadari bahwa dalam sebuah hubungan pacaran seringkali berisiko mengarah pada perlakuan buruk yang dilakukan oleh pasangan.

Kondisi demikian sesuai dengan penelitian yang dilakukan oleh Aan Yuhani (2012) dan Ferlita (2008) mengenai kekerasan dalam pacaran, hasilnya yaitu semakin kurangnya pengetahuan yang dimiliki oleh seseorang, maka semakin tinggi risiko seseorang mengalami kekerasan dalam pacaran dan sebaliknya. Kemudian responden yang memilki sikap negatif atau menolak kekerasan dalam berpacaran mayoritas memiliki keyakinan atau mengetahui bahwa kekerasan dalam berpacaran adalah hal yang tidak baik untuk dilakukan, memiliki perasaan yang tidak menyukai atau tidak nyaman terhadap kekerasan dalam berpacaran.

Hasil tersebut sesuai dengan pendapat Mann dalam Azwar (2000), ia mengungkapkan seseorang yang memiliki sikap yang negatif terhadap kekerasan dalam berpacaran memiliki pengetahuan, pemahaman dan keyakinan (kognitif) yang negatif terhadap kekerasan dalam berpacaran. Mereka mengetahui bahwa kekerasan adalah hal yang tidak wajar untuk dilakukan atau diterima, mengetahui bahwa kekerasan adalah hal yang salah dan meyakini bahwa pemukulan terhadap 
pasangan tidak boleh dilakukan dengan alasan cinta.

Berdasarkan teori yang telah dikemukakan, dapat disimpulkan bahwa responden yang memiliki pengetahuan cukup dan kurang harus lebih diperhatikan dan diberikan pengetahuan mengenai kekekerasan dalam pacaran sehingga mengurangi risiko terjadinya kekerasan pada responden tersebut.

\section{Lamanya pacaran}

Dari hasil penelitian yang dilakukan pada 162 responden, didapatkan hasil yaitu ada hubungan antara lamanya pacaran dengan kejadian kekerasan dalam pacaran di SMAN 9 Cirebon Tahun 2014. Hasil tersebut didukung oleh penelitian yang dilakukan oleh Lewis \& Fremouw, Ray \& Gold, Billingham (2006) mengungkapkan bahwa semakin lama durasi suatu hubungan, maka dating violence dalam hubungan tersebut semakin meningkat.

Selain itu sesuai dengan pendapat Billingham, Riggs \& O'Leangry (dalam Luthra \& Gidycz, 2006) yang mengatakan bahwa dating violence lebih sering terjadi di hubungan yang lebih serius dan dalam durasi yang cukup lama yaitu setiap pertambahan durasi 6 bulan, maka kekerasan dalam hubungan tersebut akan semakin meningkat (Saam Zulfan, 2012).

Cinta romantis memiliki komponen seksual dan hasrat yang kuat, dan seringkali menonjol di bagian awal relasi cinta (Santrock, 2007). Namun, semakin lama seseorang menjalin hubungan pacaran (dating) maka semakin berisiko terjadi kekerasan dalam pacaran, korban merasa kesulitan untuk menolak atau melawannya karena rasa sayang atau cinta terhadap pasangannya sudah besar. Teori diatas didukung oleh pendapat O'Kefee (2005) yang mengatakan bahwa korban dari kekerasan berulang kali akan lebih bisa bertahan dalam hubungan yang dijalaninya, daripada korban yang mengalami sekali kekerasan atau dengan kata lain, semakin sering dilakukan suatu kekerasan kepada pasangannya maka pelaku akan semakin merasa bahwa si korban menerima perilaku kekerasan tersebut (Saam Zulfan, 2012).

Berdasarkan beberapa teori, peneliti menyimpulkan bahwa semakin lama seseorang menjalani hubungan pacaran maka risiko terjadinya kekerasan semakin meningkat. Keadaan tersebut dapat dikurangi dengan cara memberikan pengetahuan tentang kekerasan dalam berpacaran pada mereka yang telah lama menjalin hubungan pacaran, baik dalam bentuk penyuluhan maupun akses internet bersama dalam pengawasan terkendali di sekolah.

\section{Kecerdasan emosional}

Berdasarkan hasil penelitian kepada 162 responden yang sedang dan pernah berpacaran didapatkan hasil tidak terdapat hubungan yang bermakna antara kecerdasan emosional dengan kejadian kekerasan dalam pacaran di SMAN 9 Cirebon Tahun 2014. Hasil penelitian ini tidak sesuai dengan penelitian yang dilakukan oleh Untari Prihatsari (2008) yang mengungkapkan bahwa semakin tinggi kecerdasan emosional seseorang maka akan cenderung menolak kekerasan yang dialaminya.

Adanya ketidaksesuaian tersebut disebabkan banyak faktor, salah satunya yaitu karena semua responden pada penelitian ini berusia dibawah 20 tahun, dengan mayoritas berumur 17 tahun (usia remaja menengah). Pada usia tersebut, remaja memiliki perilaku yang labil dan mengalami transisi dalam hal emosi. Hal ini didukung oleh pendapat yang dikemukakan Kusmiran (2011) bahwa karakteristik remaja diantaranya adalah perilaku yang labil dan berubah-ubah, ingin mendapat kebebasan dari orang tua, dan pengembangan hubungan pribadi yang labil. Masa transisi yang dialami remaja berkaitan dengan perubahan bentuk tubuh, emosi, kehidupan sosial, nilai moral, dan pemahaman.

Pendapat tersebut didukung juga oleh teori kematangan emosional menurut Hurlock (1990), yang mengatakan bahwa seorang remaja dikatakan memiliki emosi yang matang apabila dapat melakukan kontrol diri yang bisa diterima secara sosial. Individu 
yang emosinya matang mampu mengontrol ekspresi emosi yang tidak dapat diterima secara sosial. Seseorang yang telah mencapai kematangan emosional akan cenderung dapat membedakan hal yang baik dan yang buruk untuk diterima secara sosial (Santrock, 2007).

Berdasarkan teori yang telah dipaparkan oleh para ahli, dapat disimpulkan bahwa pada umumnya remaja masih mengalami perkembangan emosi (transisi) artinya remaja belum mencapai kematangan emosional. Hal tersebut yang mengakibatkan remaja cenderung belum dapat membedakan hal yang baik dan buruk sehingga kecerdasan emoisonal remaja bukan tolok ukur bermakna yang dapat mempengaruhi terjadinya kekerasan.

Hal tersebut diperkuat oleh penelitian yang dilakukan oleh Ferlita (2008) hasilnya yaitu responden yang berusia 20 tahun dan 21 tahun cenderung menunjukkan sikap yang negatif (menolak kekerasan). Pada responden yang berusia 20 tahun terdapat 7 responden $(77,8 \%)$ yang cenderung memiliki sikap negatif dan pada usia 21 tahun terdapat 3 responden $(75 \%)$ cenderung memiliki sikap negatif.

Dalam penelitian diatas responden yang berusia 20 tahun dan 21 tahun menyatakan bahwa mereka menghargai suatu hubungan tanpa adanya pemaksaan dan penganiayaan. Artinya responden tersebut lebih matang emosinya daripada usia dibawahnya dan dapat mengontrol ekspresi emosinya serta melakukan perilaku yang tepat untuk diterima secara sosial sehingga memiliki kecenderungan bersikap negatif atau menolak terhadap kekerasan dalam berpacaran. Pernyataan tersebut sesuai jika dibandingkan dengan penelitian yang dilakukan d SMAN 9 Cirebon, yang semua

\section{KESIMPULAN}

Berdasarkan hasil penelitian dapat diambil kesimpulan bahwa sebagian besar remaja perempuan kelas $X$ dan XI di SMAN 9 Cirebon memiliki tingkat pengetahuan cukup, memiliki durasi lamanya pacaran $>6$ bulan, memiiliki kecerdasan emosional rendah dan respodennya berusia dibawah 20 tahun dan belum mencapai kematangan emosi.

Selain hal yang tersebut diatas, masih banyak faktor lain yang menyebabkan kekerasan dalam pacaran selain kecerdasan emosional diantaranya yaitu budaya patriarki yang melekat di Indonesia yang beranggapan bahwa seorang perempuan adalah makhluk nomor dua dibawah pria. Pernyataan ini didukung oleh Som (2006) yang mengungkapkan bahwa lingkungan patriarki memegang peranan sangat penting dalam terjadinya kekerasan terhadap perempuan. Hal tersebut secara tidak langsung membatasi hak wanita untuk menyuarakan isi hati dan fikiran, sehingga ketika mendapat perlakuan kekerasan, seringkali mereka diam untuk menjaga nama baik sendiri dan nama baik bersama untuk menghindari perpisahan (Santrock, 2007).

Faktor lain seperti pengalaman pribadi, pengaruh orang lain yang dianggap penting (orang tua dan teman sebaya), pengaruh kebudayaan, media massa, lembaga pendidikan dan lembaga agama serta faktor emosional memiliki banyak pengaruh $(93,5 \%)$ terhadap terjadinya kekerasan dalam pacaran (Azwar, 1995). Berdasarkan banyaknya faktor yang telah diungkapkan oleh para ahli, maka peneliti berpendapat bahwa kecerdasan emosional bukan satu-satunya hal yang mempengaruhi terjadinya kekerasan dalam pacaran, masih banyak faktor lain yang tidak dijadikan variabel oleh peneliti sehingga hasil penelitian yang menyatakan tidak adanya hubungan antara kecerdasan emosional dengan kejadian kekerasan dalam pacaran dikarenakan kejadian kekerasan tersebut lebih dipengaruhi oleh faktor lain seperti budaya patriarki, pengaruh orang lain (orang tua dan teman sebaya), kebudayaan dan media massa.

sebagian besar remaja perempuan mengalami kekerasan dalam pacaran. Terdapat hubungan antara pengetahuan remaja perempuan tentang kekerasan dalam pacaran dengan kejadian kekerasan dalam pacaran di SMAN 9 Cirebon Tahun 2014, 
Nina N.M. dan Yayu I.M., Poltekkes Tasikmalaya: pengetahuan, kecerdasan, kekerasan, pacaran

terdapat hubungan antara lamanya pacaran dengan kejadian kekerasan dalam pacaran di SMAN 9 Cirebon Tahun 2014, dan tidak

\section{SARAN}

Sebaiknya penelitian ini dapat dijadikan bahan pertimbangan untuk memberikan materi kesehatan reproduksi yang didalamnya terdapat materi mengenai kekerasan dalam pacaran melalui penyuluhan maupun media masa internet dengan

\section{REFERENSI}

Anisa, Rifka. 2012. Kekerasan dalam Pacaran (Dating Violence). http://rifkaanisa.blogdetik.com. Diposting pada tanggal 23-10-2012. Diakses pada tanggal 13-02-214.

Ayu, Suci Mustiva. 2012. Kekerasan Dalam Pacaran dan Kecemasan Remaja Putri di Kabupaten Purworejo. http://journal.uad.ac.id. Diakses tanggal 13-02-2014

Ferlita, Gracia. 2008. Sikap Terhadap Kekerasan Dalam Berpacaran (penelitian pada mahasiswi reguler universitas Esa Unggul yang memiliki pacar). http://digilib.esaunggul.ac.id diakses tanggal 13-02-2014

Komalasari, Intan \& Iwan Andhyantoro. 2012. Kesehatan Reproduksi untuk Mahasiswa Kebidanan dan Keperawatan. Jakarta:Salemba Medika

Kusmiran, Eny. 2011. Kesehatan Reproduksi Remaja dan Wanita. Jakarta:Salemba Medika

Notoatmodjo, Soekidjo. 2012. Metodologi Penelitian Kesehatan. Jakarta:Rineka Cipta terdapat hubungan antara kecerdasan emosional dengan kejadian kekerasan dalam pacaran di SMAN 9 Cirebon Tahun 2014.

pengawasan terkendali. Tenaga kesehatan diharapkan dapat memberikan penyuluhan kepada remaja khususna remaja perempuan tentang kesehatan reproduksi yang didalamnya terdapat materi mengenai kekerasan dalam pacaran.

Prihatsari, Untari.2008. Sikap Perempuan Dewasa Awal Terhadap Kekerasan Dalam Pacaran Ditinjau dari Kecerdasan Emosional. http://eprints.unika.ac.id. Diakses tanggal 13-02-2014

Saam, Zulfan \& Sri Wahyuni.2012. Psikologi Keperawatan.Jakarta: PT Raja Grafindo Persada

Santrock, John W. 2007. Remaja.Jakarta : Erlangga

Sarwono, Sarlito W. 2011. Psikologi Remaja.Jakarta:PT.Raja Grafindo Persada

Set, Sony. 2009. Teen Dating Violence. Yogyakarta

Wawan, A \& dewi M. 2011. Pengukuran Pengetahuan, Sikap, dan Prilaku Manusia.Yogyakarta:Nuha Medika Yuhani, Aan. 2012. Hubungan Antara Pengetahuan Perempuan Remaja Awal Tentang Kekerasan Dalam Pacaran dengan Perilaku Kekerasan Dalam Pacaran di SMK Negeri 1 Kedawung Tahun 2014. 